\title{
ANALISA PENGARUH VARIASI SUSUNAN TERHADAP KEMAMPUAN UNJUK KERJA POMPA HYDRAM DITINJAU DARI ASPEK TINGGI TERJUNAN AIR
}

\author{
Rudy Sutanto*, Made Wirawan** \\ * Dosen Jurusan Teknik Mesin Universitas Mataram Ntb, Jl. Majapahit No 62 Mataram \\ ** Dosen Jurusan Teknik Mesin Universitas Mataram Ntb, Jl. Majapahit No 62 Mataram
}

\begin{abstract}
Cultivation activities, both in the development of food crops, horticulture, livestock and plantations. Availability of water is a strategic factor. Specific areas adjacent to the water source or location are under the eyes water, water needs are less of a problem. However, the ground reality is not always flat; there is the hilly or bumpy. Land surface area is higher than the water source and the bumpy areas will have trouble getting a continuous supply of water. Therefore need to find an alternative to reduce the burden. One alternative is that hydram pump hydraulic work without using gasoline. Hydram pump was applied to a small debit them to raise water and drinking water needs of households. However, the use for irrigation in dry land agriculture that requires a large output flow is unknown. The method used in this research is to create models in the laboratory to simulate the independent variables of pressure (high falling) water flow while bound variables measured include debit and results of hydraulic pressure. The results of experiments that analyzed the correlation between independent variables and the variables are bound to get hydram pump efficiency.

Pumps that were realized and tested in the laboratory have the following specifications: input $=1.5$ inch diameter; output diameter $=0.5$ inches; step on the valve piston waste $=5 \mathrm{~mm}$; air tube diameter $=3$ inches; air tube length $=24 \mathrm{~cm}$; material with galvanized pipe, construction of hydram pump consisting of the first arrangement of input - waste valves - compressor (ILK) and the second arrangement of input compressor - waste valve (IKL). Pump of hydram with arrangement ILK has the ability to better performance when compared with the composition of IKL. Where pump of hydram with the composition of ILK has the best efficiency at 2.5 meters high waterfall with a debit enter 2.458 liters / sec discharge output capable of being lifted by a pump at 0087 liters / sec while the high lift or vertical height of the pump which is equal to 30 meters and efficiency pump of hydram which is equal to $13.6 \%$.
\end{abstract}

Keyword : hydram pump, valve waste, air tube, arrangement of pump, peformance

\section{Pendahuluan}

Air merupakan kebutuhan mutlak bagi kelangsungan kehidupan, tanpa air tidak akan ada kehidupan di dunia ini. Khusus daerah- daerah yang berdekatan dengan sumber air atau lokasinya berada di bawah mata air, kebutuhan air tidak terlalu menjadi masalah. Sesuai dengan hukum fisika, air dengan sendirinya akan mengalir dari tempat yang tinggi ke tempat yang lebih rendah. Namun, kenyataannya permukaan tanah itu tidak selalu rata, ada daerah yang berbukit-bukit atau bergelombang. Daerah yang permukaan tanahnya lebih tinggi daripada sumber air dan daerah yang bergelombang, akan mengalami kesulitan mendapatkan pasokan air secara kontinu.

Salah satu upaya untuk memenuhi kebutuhan air, terutama di lokasi yang posisinya lebih tinggi daripada mata air adalah menggunakan pompa air. Jenis pompa yang lazim digunakan saat ini adalah pompa air bertenaga motor listrik yang menggunakan bahan bakar minyak (solar atau bensin). Untuk daerah perkotaan kebutuhan BBM tidak terlalu menjadi masalah. Sementara itu dari data yang berhasil dihimpun bahwa didaerah pedesaan atau daerah terpencil keberadaan BBM sangat langkah, bila ada, harganyapun sangat mahal. Untuk mengatasi masalah inilah timbul pemikiran untuk menggunakan pompa air tanpa motor listrik sehingga tidak memerlukan BBM. Hal ini dipenuhi oleh pompa hydram sebagai pilihan tepat, namun demikian berapa sesungguhnya tinggi dan sudut terjunan air dari pompa ke permukaan sumber air yang ideal dan berapa ukuran kompresor yang dapat digunakan untuk menaikkan air secara maksimum serta debit yang dihasilkan serta head pompa yang dihasilkan belum diketahui secara pasti. Sehingga perlu segera dilakukan penelitian secara menyeluruh untuk mengetahui peformance dan dimensi dari pompa hydram.

\section{Tinjauan Pustaka}

Kenaikan bahan bakar minyak (BBM) telah berpengaruh pada penggunaan pompa air oleh masyarakat pedesaan. Bagi masyarakat petani, kondisi ini sangat berpengaruh pada peningkatan hasil pertanian, karena salah satu alat untuk mengairi sawah adalah pompa hidram yang menggunakan bahan bakar minyak. Biaya produksi menjadi meningkat sebagai akibat dari naiknya harga bahan bakar minyak, sedangkan hasil produksi pertanian cenderung stagnan. Hal ini membuat tingkat pendapatan petani semakin rendah dan sangat membebani kehidupan para petani (Wahyudi, 2000). Oleh sebab itu perlu dicari suatu alternatif untuk mengurangi beban tersebut. Salah satu 
alternatif adalah pompa hidram yang bekerja secara hidrolik tanpa menggunakan BBM.

Pompa hidraulik ram (hidram) memanfaatkan tenaga aliran air yang jatuh dari tempat suatu sumber dan sebagian dari air itu dipompakan ke tempat yang lebih tinggi. Pada berbagai situasi, penggunaan pompa hidram memiliki keuntungan dibandingkan penggunaan jenis pompa lainnya, yaitu tidak membutuhkan bahan bakar atau tambahan tenaga dari sumber lain, tidak membutuhkan pelumasan, bentuknya sederhana, biaya pembuatannya serta pemeliharaannya murah dan tidak membutuhkan ketrampilan tinggi untuk membuatnya. Pompa ini dapat bekerja dua puluh empat jam per hari (Bjarnegard, 2004).

Pompa tanpa bahan bakar yang diteliti ini diharapkan dapat dimanfaatkan untuk membantu mengurangi biaya operasional untuk irigasi pertanian dan drainase pasang surut (Wahyudi, 2004). Disamping yang selam ini diimplementasikan untuk memenuhi kebutuhan air bersih rumah tangga. Berikut disampaikan hasil kajian literatur tentang deskripsi, konsep, persyaratan penerapan dan sistem kerja pompa hidram.

Pompa hidram merupakan suatu alat yang digunakan untuk menaikkan air dari tempat rendah ke tempat yang lebih tinggi. Penggunaan pompa hidram tidak terbatas hanya pada penyediaan air untuk kebutuhan rumah tangga, tetapi juga dapat digunakan untuk memenuhi kebutuhan air untuk pertaniaan, peternakan dan perikanan darat. Di beberapa daerah pedesaan di Jepang, alat ini telah banyak digunakan baik sebagai penyediaan air untuk kegiatan pertanian maupun untuk keperluan domestik. Konsep dari pompa air tanpa mesin ini adalah untuk memompa atau menaikkan air dari tempat rendah ke tempat yang lebih tinggi dengan cara kerja yang sederhana dan efektif dan tanpa menggunakan mesin sehingga mudah dan hemat operasionalnya tanpa BBM (Widarto et al., 2001).

Sumber energi dari pompa berasal dari tekanan dinamik atau gaya air yang timbul karena perbedaan ketinggian dari sumber air / asal air ke pompa. Gaya tersebut akan dipergunakan untuk menggerakkan katup sehingga diperoleh gaya yang lebih besar untuk mendorong air ke atas (Amat Sairi, 2000 \& Trimatmodjo, 1999).

Penggerak mula pompa hidram menggunakan energi akibat dari adanya perbedaan ketinggian permukaan air sumber dengan kedudukan pompa. Manfaat alat ini adalah memompa air ke tempat yang lebih tinggi. Tenaga air maksimum dapat dihasilkan 8 kali air terjunan. Kondisi yang umum digunakan pompa hidram adalah topografi yang sulit, sumber air jauh lebih rendah dari lokasi pemakai (Edy S. et al., 2004).

Persyaratan penerapan pompa hidram yang pertama adalah tersedianya air baku yang cukup dan kontinu, tinggi terjunan air terhadap kedudukan pompa terpenuhi, tinggi lokasi yang akan disuply dari kedudukan pompa proporsional, kemiringan menampung air baku dari pompa hidram antara kedudukan pompa dengan daerah yang disupply (Wahyudi, 2005a).

Cara kerja pompa hidram diawali dengan aliran air dari sumber masuk melalui pipa pemasukan atau pipa penghubung dan keluar dari katup limbah. Gaya tekan air yang masuk ke dalam pompa akan mendorong katup-katup tersebut sehingga memaksa katup tersebut menutup dan menghentikan aliran di pipa pemasukan. Kondisi ini menyebabkan adanya gaya tekan dari pipa pemasukan dan memaksa air untuk mengalir ke pipa pengeluaran dengan tekanan tinggi sehingga mampu dialirkan ke lokasi yang lebih tinggi (Balitbang PU, 2005).

Tekanan tinggi dalam pompa juga akan mengatasi tekanan dalam ruang udara pada katup penghantar sehingga katup akan terbuka dan air akan terus mengalir lagi dari pipa penghubung. Perputaran ini berlangsung berulang-ulang dengan frekuensi yang sangat cepat (Tessema, 2000).

\section{Metode Penelitian \\ Tahapan Kegiatan}

Penelitian ini dilakukan dengan tahapan-tahapan sebagai berikut :

a. Survey kondisi lapangan yang ada.

b. Membuat model di laboratorium, dengan mensimulasi variabel bebas berupa tinggi jatuh air, debit aliran sedangkan variabel terikatnya yang diukur meliputi debit hasil dan tekanan hidrolik.

c. Data hasil experimen kemudian dianalisis berupa korelasi antara variabel variabel bebas dan variabel terikat. Sehingga dapat dipresentasikan dalam bentuk grafik.

Variabel-variabel yang akan diteliti dalam penelitian ini dibedakan menjadi variabel bebas (independent variable) dan variabel terikat (dependent variable)

a. Variabel Bebas

Variabel bebas (independent variable) dalam penelitian ini adalah tinggi jatuh air dari sumber ke pompa hidram $\left(\mathrm{H}_{1}\right)$ dalam satuan meter $(\mathrm{m})$, debit air input $\left(\mathrm{Q}_{1}\right)$ dalam satuan $1 \mathrm{t} / \mathrm{menit}$ atau $\mathrm{m}^{3} / \mathrm{dtk}$ dan dimensi Pompa (D) dalam satuan $\mathrm{mm}$.

b. Variabel Terikat

Variabel terikat (dependent variable) dalam penelitian ini adalah tinggi hidrolik hasil $\left(\mathrm{H}_{2}\right)$ dalam satuan meter $(\mathrm{m})$, dan debit hasil $\left(\mathrm{Q}_{2}\right)$ dalam satuan $1 \mathrm{t} / \mathrm{menit}$.

Untuk mengetahui parameter input dan output, dilakukan pengukuran dengan kriteria sebagai berikut:

- Tinggi tekanan input (H1 ; tinggi terjunan) diukur jarak vertikal dari elevasi air di reservoir sampai ke pompa hidram. Pada penelitian ini dilakukan 5 variasi tinggi yakni $2 ; 2,5 ; 3 ; 3,5 ; 4$ meter.

- Tinggi tekanan output (H2) diukur dengan menggunakan pressure gauge yakni jarak vertikal dari pompa sampai dengan reservoir.

- Debit input (Q1) dan debit output (Q2) diukur langsung. 


\subsection{Eksperimen Di Laboratorium}

Pompa yang direalisasikan dan dicoba di laboratorium memiliki spesifikasi sebagai berikut : diameter input $=1,5$ inci ; diameter Output $=0,5$ inci dan langkah torak pada katup limbah $=5 \mathrm{~mm}$, dengan posisi katup limbah terletak sebelum dan setelah tabung udara serta ukuran tabung udara : diameter 3 inci dan tinggi $24 \mathrm{~cm}$.

Prinsip kerja pompa hidram yang dicoba adalah sebagai berikut:

- Akhir siklus sebelumnya, kecepatan air melalui ram mulai bertambah, air melalui katup limbah yang sedang terbuka, timbul tekanan negatif yang kecil dalam ram

- Aliran bertambah sampai maksimum melalui katup limbah yang terbuka dan tekanan dalam pipa pemasukan juga bertambah secara bertahap.

- Katup limbah mulai menutup dengan demikian menyebabkan naiknya tekanan dalam hidrulik ram. Kecepatan aliran dalam pipa pemasukan telah mencapai maksimum.

- Katup limbah tertutup, menyebabkan terjadinya palu air (water hammer) yang mendorong air melalui katup pengantar. Kecepatan aliran pipa pemasukan berkurang dengan cepat.

- Denyut tekanan terpukul ke dalam pipa pemasukan, menyebabkan timbulnya hisapan kecil dalam hidraulik ram. Katup limbah terbuka karena hisapan tersebut dan juga karena beratnya sendiri. Air mulai mengalir lagi melalui katup limbah dan siklus hidraulik ram terulang lagi.

\section{Hasil Dan Pembahasan}

Dalam analisis ini disampaikan hasil perbandingan variasi tinggi terjunan dan variasi susunan pompa hydram (ada dua variasi susunan pompa : yang pertama; input - kompresor - katup limbah (IKL), sedangkan yang kedua; input - katup limbah - kompresor (ILK)) terhadap tekanan outputnya, gaya hisap serta gaya dorongnya. Kemudian dibandingkan antara debit input dan debit outputnya dan yang terakhir mendapatkan efisiensi dari pompa hydram.

Berdasar atas hasil data eksperimen laboratorium didapat bahwa untuk susunan ILK (input - katup limbah - kompresor) head maksimum cenderung tetap atau konstan seiring dengan bertambanya tinggi terjunan (garfik 1) sedangkan debit output yang dihasilkan cenderung menurun seiring dengan bertambanya tinggi terjunan (grafik 2), hal ini dikarenakan semakin tinggi terjunan berakibat pada semakin kecil debit air yang memasuki pompa dan secara tidak langsung akan mempengaruhi energi potensial yang terkandung didalam air, energi potensial inilah yang mempengaruhi kemampuan kerja pompa sehingga debit yang mampu diangkat ketempat yang lebih tinggi akan menurun meskipun head maksimum pada masing-masing variasi tinggi terjunan cenderung tetap. Sedangkan untuk susunan IKL (input kompresor - katup limbah) memiliki kecenderungan yang berbeda jika dibandingkan dengan susunan ILK yakni terjadi kecenderungan peningkatan pada head maksimum yang terjadi seiring dengan penambahan tinggi terjunan, head maksimum tertinggi yakni 26 meter terjadi pada tinggi terjunan 3 , 3.5 dan 4 meter (grafik 1), dan debit output maksimum atau tertinggi yakni sebesar 0.085 lt/dtk terjadi pada tinggi terjunan 3 meter (grafik 2). Hal ini terjadi dikarenakan pompa mengalami stagnasi yakni untuk ukuran pompa dalam penelitian ini hanya mampu menyerap energi berguna hanya pada ketinggian sampai 3 meter sedangkan selebihnya lebih banyak energi yang tidak termanfaatkan dan cenderung dibuang melalui katup limbah.

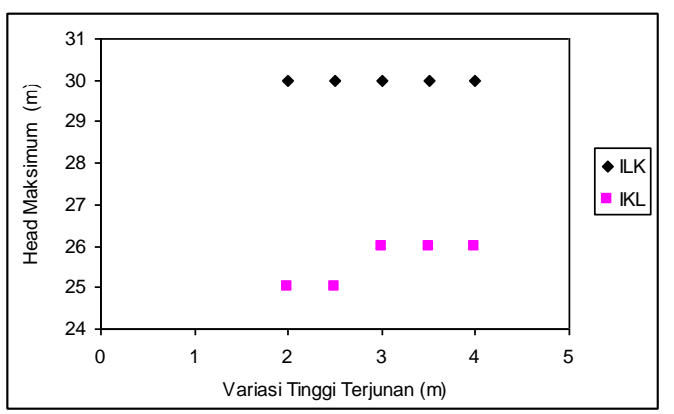

Grafik 1. Perbandingan Variasi Tinggi Terjunan dengan Tinggi Tekanan Output Maksimum

Dari kedua susunan yakni ILK dan IKL, berdasarkan grafik 1 dan grafik 2 maka susunan ILK memiliki kemampuan kerja yang lebih baik jika dibandingkan dengan susunan IKL hal ini terjadi diakibatkan karena energi hisap yang dilakukan pompa atau energi dorong yang terjadi akibat tinggi terjunan langsung dapat dimanfaatkan atau digunakan tabung kompresor untuk menggerakan katup sehingga energi tersebut dapat dimanfaatkan pertama kali secara langsung oleh kompresor untuk menaikkan tekanan didalamnya selanjutnya digunakan untuk mendorong air keatas, tidak demikian dengan susunan IKL dimana energi pertama kali secara langsung digunakan untuk menggerakkan katup limbah selebinya barulah menggerkkan tabung kompresor.

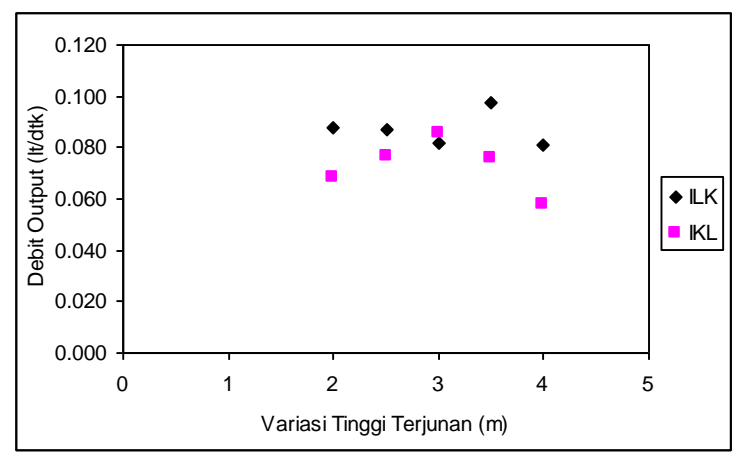


Grafik 2. Perbandingan Variasi Tinggi Terjunan dengan Debit Output

Pada pompa hydram dengan ukuran 1,5 inci pada pipa masukan pompa dan 0,5 inci untuk pipa keluaran pompa maka didapat data seperti terlihat pada grafik.2 bahwa untuk susunan ILK debit maksimum yakni sebesar $0.098 \mathrm{lt} / \mathrm{dtk}$ terjadi pada tinggi terjunan 3.5 meter sedangkan untuk susunan IKL debit maksimum yakni sebesar $0.085 \mathrm{lt} / \mathrm{dtk}$ terjadi pada tinggi terjunan 3 meter.

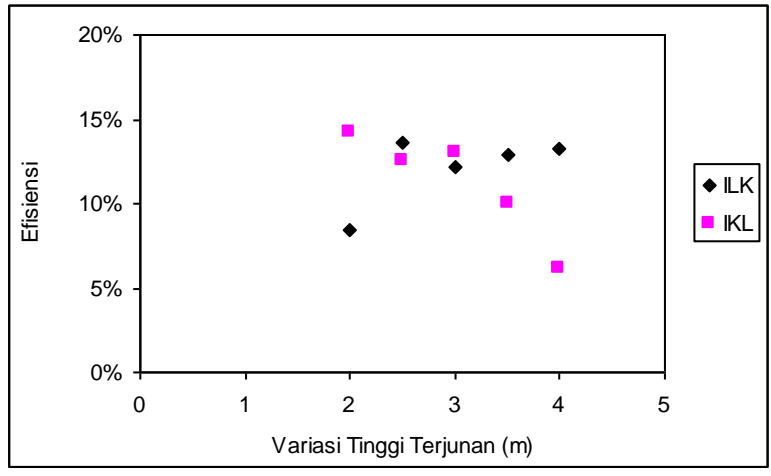

Grafik 3. Perbandingan Variasi Tinggi Terjunan dengan Efisiensi

Sedangkan pada grafik.3 untuk susunan IKL kecenderungan efisiensinya akan semakin menurun seiring dengan bertambahnya tinggi terjunan, hal ini lebih dikarenakan kemampuan pompa memiliki keterbatasan atau kemampuan pompa memiliki batas maksimum energi dinamis yang dapat dimanfaatkan untuk suatu ukuran pompa, sehingga sebagian besar debit air yang dimasukkan kedalam pompa hanya dibuang begitu saja melewati katup limbah dan sebagian kecil yang dapat dinaikkan atau dimanfaatkan. Sedangkan untuk susunan ILK justru efisiensinya akan semakin naik seiring dengan bertambahnya tinggi terjunan, hal ini lebih dikarenakan energi dinamis yang dapat dimanfaatkan pompa dapat lebih optimal termanfaatkan, sehingga sebagian besar debit air yang dimasukkan kedalam pompa dapat dinaikkan atau disalurkan keatas yakni ke tempat yang lebih tinggi.

Sehingga untuk pompa ukuran 1,5 inci dengan susunan ILK memiliki efisiensi terbaik pada tinggi terjunan 2.5 meter dengan debit masukkan 2,458 liter/detik sedang debit keluaran yang mampu diangkat oleh pompa sebesar 0.087 liter/detik sedangkan tinggi angkat atau tinggi vertikal dari pompa yakni sebesar 30 meter serta efisiensi pompa hydram yakni sebesar 13.6 $\%$ seperti yang tertuang dalam grafik.3. sedangkan untuk susunan IKL memiliki efisiensi terbaik pada tinggi terjunan 2 meter dengan debit masukkan 2,302 liter/detik sedang debit keluaran yang mampu diangkat oleh pompa sebesar 0.068 liter/detik sedangkan tinggi angkat atau tinggi vertikal dari pompa yakni sebesar 25 meter serta efisiensi pompa hydram yakni sebesar 14.2 $\%$.

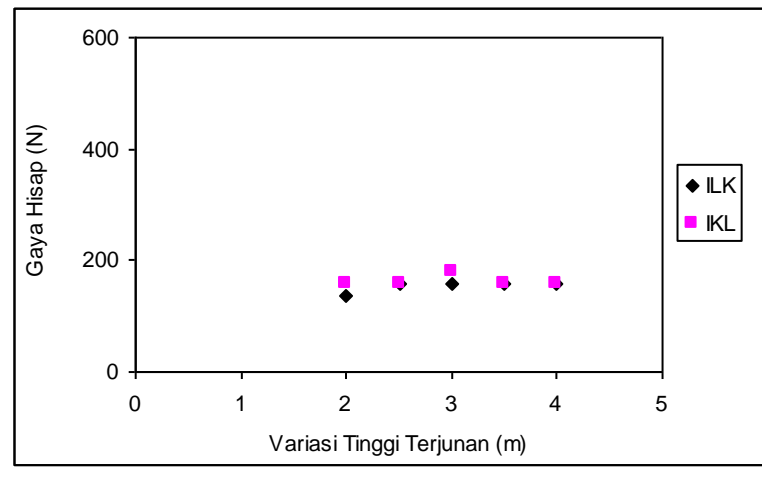

Grafik 4. Perbandingan Variasi Tinggi Terjunan dengan Gaya Hisap

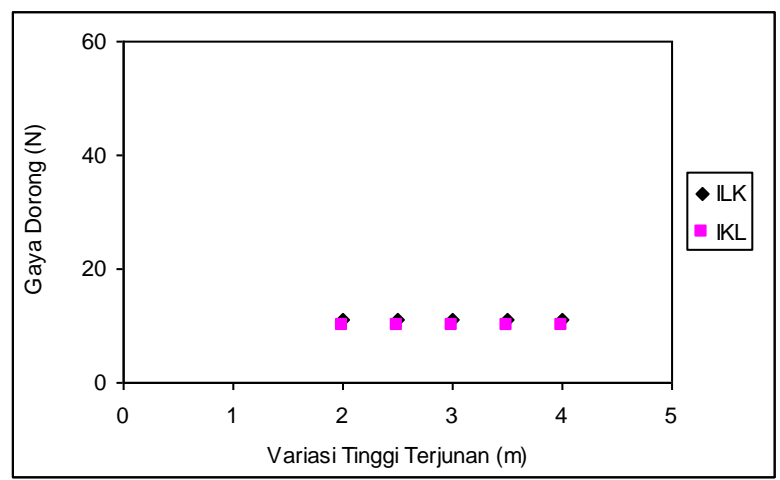

Grafik 5. Perbandingan Variasi Tinggi Terjunan dengan Gaya Dorong

Penggerak mula pompa hidram menggunakan energi akibat dari adanya perbedaan ketinggian permukaan air sumber dengan kedudukan pompa, semakin tinggi perbedaan antara sumber air dengan pompa (tinggi terjunan) maka kecenderungan gaya hisap atau gaya tekan air yang memasuki pompa cenderung tetap atau stabil hal ini dikarenakan bahwa tinggi terjunan kurang berpengaruh secara signifikan terhadap perubahan head dinamik yang dikandung oleh air sehingga secara tidak langsung energi dinamik yang dikandung akan cenderung tidak berubah seiring dengan bertambanya ketinggian terjunan, seperti terlihat pada grafik. 4 .

Gaya hisap atau gaya tekan air yang masuk ke dalam pompa akan mendorong katup-katup tersebut sehingga memaksa katup tersebut menutup dan menghentikan aliran di pipa pemasukan. Kondisi ini menyebabkan adanya gaya tekan dari pipa pemasukan dan memaksa air untuk mengalir ke pipa pengeluaran dengan tekanan tinggi sehingga mampu dialirkan ke lokasi yang lebih tinggi. Tekanan tinggi dalam pompa juga akan mengatasi tekanan dalam ruang udara pada katup penghantar sehingga katup akan terbuka dan air akan terus mengalir lagi dari pipa penghubung, sehingga semakin tinggi terjunan maka gaya dorong air ke tempat yang lebih tinggi cenderung stabil atau tetap (grafik. 5).

\section{Kesimpulan Dan Saran Kesimpulan}


- Pompa yang direalisasikan dan dicoba di laboratorium memiliki spesifikasi sebagai berikut : diameter input $=1,5$ inci $;$ diameter output $=0,5$ inci ; langkah torak pada katup limbah $=5 \mathrm{~mm}$; diameter tabung udara $=3$ inci ; panjang tabung udara $=24 \mathrm{~cm}$; bahan pompa pipa galvanis, susunan pompa hydram terdiri dari yang pertama susunan input - katup limbah - kompresor (ILK) dan yang kedua susunan input - kompresor - katup limbah (IKL).

- Pompa hydram ukuran 1,5 inci dengan susunan ILK memiliki efisiensi terbaik pada tinggi terjunan 2.5 meter dengan debit masukkan 2,458 liter/detik sedang debit keluaran yang mampu diangkat oleh pompa sebesar 0.087 liter/detik sedangkan tinggi angkat atau tinggi vertikal dari pompa yakni sebesar 30 meter serta efisiensi pompa hydram yakni sebesar $13.6 \%$. sedangkan untuk susunan IKL memiliki efisiensi terbaik pada tinggi terjunan 2 meter dengan debit masukkan 2,302 liter/detik sedang debit keluaran yang mampu diangkat oleh pompa sebesar 0.068 liter/detik sedangkan tinggi angkat atau tinggi vertikal dari pompa yakni sebesar 25 meter serta efisiensi pompa hydram yakni sebesar $14.2 \%$.

\section{Saran}

- Pada penelitian selanjutnya perlu dilakukan modifikasi alat (diantaranya : jumlah katup bilas dan jumlah tabung udara) sehingga dihasilkan debit air output yang besar untuk keperluan irigasi pada daerah lahan kering.

- Memvalidasi korelasi antar variabel-variabel tersebut untuk dijadikan rencana implementasi pompa hydram.

\section{Daftar Pustaka}

Agusto, WM, 2006, "Pompa Hydram", Subang, LIPI.

Balitbang PU, 2005, Penjelasan Teknologi Pompa Hidram, PT Medias, Yayasan Penerbit PU, Jakarta

Bambang Tri Atmodjo. 1996. Hidraulika I. Edisi ke 2. Yogyakarta: Beta Offset.

Bjarnegard, Frederik, et al, 2004, Ram Pump and Solar Pump Training, Border Green Energy Team, dalam www.bget.org

Edy Supriyanto, Firdaus Ubaidillah, Gaguk Jatisukamto, Upaya Pengadaan Air Bersih melalui Pembuatan Pompa Hidram, Laporan Penelitian, FMIPA, Universitas Jember

L. Widarto, FX. Sudarto, 2002, "Membuat Pompa Hidram”, Kanisius - Yogyakarta.

S. Imam Wahyud Dan Fauzi Fachrudin , 2008, Korelasi Tekanan Dan Debit Air Pompa Hidram Sebagai Teknologi Pompa Tanpa Bahan Bakar Minyak, Prosiding Seminar Nasional Sains dan Teknologi-II 2008 Universitas Lampung, ISBN : 978-979-116574-7, p. XI-60 - 70.

Tessema, A.W, 2000, Hydraulic Ram System Design and Application, ESME, dalam http://home
att.net/-africantech/ESME/hydram2/ HydRam2.htm

Wahyudi, S. Imam, 2001, Uji Hipotesis terhadap Faktor Penyebab Banjir Rob Kota Semarang, Prosiding Seminar Nasional ITS, ISBN, 979-96565-08, p.A13-1 s/d A13-6

Wahyudi, S. I., Montillet Agnes, Khalifa A., 2002, Darcy and Post-Darcy Flow within Different Sands, Journal of Hydraulic Research, Delf, Vol. 40, No. 4, p519-525. 